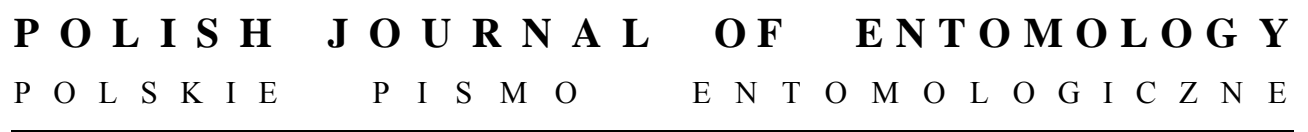

VOL. 80: 729-745

Gdynia

31 December 2011

DOI: $10.2478 / \mathrm{v} 10200-011-0055-7$

\title{
The oldest representatives of the subfamilies Meligethinae (Coleoptera: Nitidulidae) and Brontinae (Coleoptera: Silvanidae) from Baltic amber and some evolutionary notes
}

\author{
ALEXANDR G. KIREJTSHUK \\ Zoological Institute of the Russian Academy of Sciences, Universitetskaya Emb. 1, \\ St. Petersburg, 199034, Russia; \\ Muséum National d'Histoire Naturelle, Entomologie, 45 Rue Buffon, F- 75005 Paris, \\ France, e-mails: kirejtshuk@gmail.com,agk@zin.ru
}

\begin{abstract}
The paper describes Melipriopsis rasnitsyni gen. et sp. n. (Nitidulidae, Meligethinae) and Dendrobrontes popovi gen. et sp. n. (Silvanidae, Brontinae) from Baltic amber. The systematic position and phylogenetic significance of the new genera and species are discussed. A review of the fossils of the families Nitidulidae and Silvanidae is given. The genus Sinisilvana HoNG, 2002, for which the family Sinisilvanidae HONG, 2002 was proposed, is considered as a genus with an unclear position within Silvanidae.
\end{abstract}

KEY WORDS: Coleoptera, Nitidulidae, Meligethinae, Silvanidae, Brontinae, new genera, new species, Baltic amber.

\section{INTRODUCTION}

The families Nitidulidae LATREILLE, 1802 and Silvanidae KIRBY, 1837 are represented in materials from different outcrops beginning from the Lower Cretaceous, although most fossils from these families are still undescribed. Nitidulidae is known from the Lower Cretaceous, represented by the palaeoendemic Crepuraea KIREJTSHUK in KIREJTSHUK et PonOMARENKO, 1990 (Epuraeinae KIREJTShUK, 1986) and Cyllolithus KIREJTSHUK in KIREJTSHUK et PONOMARENKO, 1990 (Nitidulinae sensu stricto). RASNITSYN \& Ross (2000) mentioned this family in the list of groups found in Lower Cretaceous Burmese amber. The other Nitidulidae recorded in fossils were obtained from Cenozoic outcrops. 
Most of them originated from Baltic amber: Epuraea ERICHSON, 1843 (including Epuraeanella CROTCH, 1874) and palaeoendemic Baltoraea KUROCHKIN et KIREJTSHUK, 2010 (Epuraeinae); Carpophilus STEPHENS, 1829 (Carpophilinae ERICHSON, 1842); Pria StePhens, 1830 (Meligethinae C.G. THOMSON, 1859); Nitidula Fabricius, 1775; palaeoendemic Microsoronia KIREJTSHUK et KUROCHKIn, 2010; Phenolia ERICHSON, 1843 (subgenus Lasiodites JeLíneK, 2001) and Cyllodes ERICHSON, 1843 (Nitidulinae sensu stricto); Cybocephalus ERICHSON, 1844 (Cybocephalinae JACQUELIN du VAL, 1858) (Klebs 1910, HieKe \& PietrZeniuK 1984, KireJTShUK \& KURochKin 2010, KurochKIN \& KIREJTSHUK 2010 etc.). Prints of palaeoendemic Epanurea SCUDDER, 1900 (Epuraeinae); Carpophilus (Carpophilinae); Nitidula; palaeoendemic Miophenolia WiCKHAM, 1916 and palaeoendemic Cychramites WiCKHAM, 1913 (Nitidulinae); Colopterus ERICHSON, 1942 (Cillaeinae KIREJTSHUK et AUDISIO, 1986) were recorded from Florissant of the Lower Oligocene (WICKHAM 1920, 1933 etc.). Some species of palaeoendemic Pastillocenicus KIREJTSHUK et NEL, 2008 (Cybocephalinae) were described from Lowermost Eocene French amber (Oise amber) and some species of palaeoendemic Palaeometopia KIREJTSHUK et PoINAR, 2007 Mystrops ERICHSON, 1843 and Pallodes ERICHSON, 1843 (Nitidulinae) were found in Lower Miocene Dominican amber (KirejtShuK \& Poinar 2007, KirejtShuK et Nel 2008). The genus Phenolia Erichson, 1843 is also recorded from Eocene compression deposits (Green-River, Wyoming, Utah). Prints from the Oligocene have revealed Meligethes StEPHENS, 1830 (Brunnstatt, Alsace) (Meligethinae); Prometopia ERICHSON, 1843 (Quesnel, British Columbia); Amphotis ERICHSON, 1843; palaeoendemic Oligoamphotis THÉOBALD, 1937 and Omosita ERICHSON, 1843 (Kleinkembs, Baden-Württemberg) (Nitidulinae) (HANDLIRSCH 1906-08, THÉOBALD 1937 etc.). Finally, Procarpophilus macgillavryi de JONG, 1953 (Djirah oilfield, Sumatra; ? Miocene - de JoNG, 1953: 'below beds of Baturadja stage age') Nitidula and Amphotis (Oeningen, Baden-Württemberg; Rott, Transylvania; Radoboj, Croatia); Phenolia (Wishnevaya Balka, Stavropol'sky Kray) and Cybocephalus (Mojave Desert, California) (Handlirsch 1906-08, Palmer et al. 1957, KirejtShuK et Ponomarenko 1990 etc.) have been recorded in Miocene sediments.

The information on the family Silvanidae in the fossil record is rather scanty in publications. The family is recognized as being composed of two subfamilies (Silvanidae sensu stricto and Brontinae BLANCHARD, 1845), although not infrequently it is split into more subfamilies (treated here as tribes or synonyms of Brontinae). The subfamily Silvaninae includes the palaeoendemic genus Pleuroceratos PoINAR et KIREJTSHUK, 2008 from Lower Cretaceous Burmese amber and three genera represented both in Eocene Baltic amber and in the recent fauna (Silvanus LATREILle, 1807, Airaphilus ReDTENBACHER, 1857, Nausibius REDTENBACHER, 1858), while only one genus of Brontinae (Cryptomorpha Wollaston, 1854) is known from Eocene Bitterfeld amber (KLEBS 1910, 
HANDLIRSCH 1906-08, 1925, ERMISCH 1942, BACHOFEN-ECHT 1949, LARSSON 1978, Spahr 1981, Hieke \& Pietrzeniuk 1984 etc.). The genus Sinisilvana Hong, 2002, for which the family Sinisilvanidae HoNG, 2002 was proposed, is here considered as a taxon with an unclear position within Silvanidae (according to its original description probably within the subfamily Silvaninae sensu stricto).

Traditionally the Baltic amber strata were classified in the Upper Eocene or Lower Oligocene (approximately $38 \mathrm{Ma}$ ), although it is thought this amber was re-worked to the present sediments. Recent studies have shown that the formation of the 'blue earth' containing this amber falls in the Middle Eocene, so the age of secondary deposits of this amber could be estimated as at least 50 Ma (RITZKOWSKI 1997, WeITSCHAT \& WICHARD 2010 etc.).

The specimens described here were in the collection of amber inclusions of C. and H.W. Hoffeins (Hamburg) and donated to the Deutsche Entomologische Institut (Müncheberg). They were examined using the usual optical system (Leica MZ 16.0 stereomicroscope equipped with a CCD camera). A detailed review of the representation of both families in the fossil record will be found in the catalogue by PONOMARENKO \& KirEJTSHUK (2011).

\section{Acknowledgements}

The author is pleased to express his gratitude to Christel and Hans Hoffeins (Hamburg), who sent many interesting beetles in Baltic amber for this study. He greatly appreciates the generous assistance on the part of André Nel during the study. He also has the pleasant duty to express his thanks to the Muséum national d'Histoire naturelle for providing him with the opportunity to work in this museum according to the programme for visiting professors in recent years.

The study was carried out within the framework of the programme of the Praesidium of the Russian Academy of Sciences 'Origin of biosphere and evolution of geo-biological systems' and supported by the Russian Foundation for Basic Research (grant 09-04-00789-a).

The preparation of drawings was made with assistance of the author's daughter. The author feels a pleasant duty to recognise a creative editing of this issue by Elżbieta Kaczorowska.

\section{RESULTS}

Family Nitidulidae LATREILLE, 1802

Subfamily Meligethinae C.G. Thomson, 1859

\section{Genus Melipriopsis gen. $\mathbf{n}$.}

Type species: Melipriopsis rasnitsyni sp. n. 


\section{Etymology}

The name of this genus is formed from the roots of the generic names Meligethes and Pria, and also from Greek 'opsis' (occurrences or structure resembling a (specified) thing); gender feminine.

\section{Composition}

The new genus includes only the type species.

Diagnosis

Body medium-sized, (sub) elliptical, moderately convex dorsally and subflattened ventrally. Body coarsely and sparsely punctured, elytra diffusely punctured; alutaceous to finely microreticulated; uniformly pubescent and with distinct cilia along pronotal and elytral sides. Head moderately projecting anteriorly and with anterior edge of frons truncate; antennal grooves behind mentum; mentum subtrapezoid. 11-segmented antennae bearing 3 segmented compact club. Pronotum subflattened at disk and gently sloping at narrowly bordered sides, its posterior angles with distinct top and strongly projecting posteriorly, base distinctly bordered. Elytra with narrowly bordered sides, expressed adsutural lines and oblique apices leaving only apex of pygidium uncovered. Pygidium with depression (or depressions) at base. Prosternal process flattened and not curved along procoxae, with arrow-like apex. Mesoventrite medially flattened and not excavate. Metepisterna somewhat widened anteriorly. Hypopygidium without clear depressions at base. Tibiae subtriangular; protibia uniformly finely crenulate along outer edge; meso- and metatibiae flattened and with a row of thick setae along outer edge. Tarsi with moderately lobed tarsomeres 1-3 and short subcylindrical tarsomere 4; tarsomere 5 with strong simple claws.

\section{Comparison}

This new genus shares many peculiarities with different recent genera, although it has distinct cilia along the pronotal and elytral sides, a border along the pronotal base, and epipleura clearly sloping laterally. The depressions along the base of the pygidium characteristic of the subfamily are not quite clear, although the exposed arcuate outer ends of the depression (or depressions) can be seen from under the posterior edges of the lateral parts of the previous segment. The pygidium and hypopygidium of Melipriopsis gen. $\mathrm{n}$. seem to be very similar to those in Cryptarchopria JELínEK, 1975 (having the pygidium with one interrupted basal ridge forming a depression behind it, and the hypopygidium without any clear depression at all). In addition to the cilia, bordered pronotal base and sloping epipleura, however, the new genus is easily distinguished from the latter by the more slender body with coarse and sparse puncturation of integument, the unmodified antennae, frons only slightly expanded over antennal insertions, antennal grooves of usual structure, distinct pronotosternal sutures restricting slightly elevated prosternum (instead of elevated isolated median part of prosternum in Cryptarchopria), arrow-like apex of 
prosternal process, pygidium completely exposed from under elytral apices, femora of usual shape and subtriangular tibiae. Restiopria Audisio, JeLíneK et Cline in AUDISIO et al., 2011 is another genus in the recent fauna which shares some similarity with the new genus in the structure of the abdominal apex; however, this genus has widely rounded posterior angles of the pronotum, a wider prosternal process, protibiae without teeth along the outer edge, unexplanate pronotal and elytral sides, characteristic integument sculpture, and also it has no cilia on the pronotal and elytral sides, an unbordered pronotal base, and the epipleura are not sloping. The genera Pria and Cornutopria ENDRÖDY-YoungA, 1978 (including Microporodes ENDRÖDY-YOUNGA, 1978 and Palmopria ENDRÖDY-YOUNGA, 1978) differ from the new genus in the very modified antennae, unbordered base of pronotum, trapezium-shaped meso- and metatibiae character of sculpture of integument, not sloping epipleura and lack of cilia on pronotal and elytral sides. In addition, this new genus differs from the other generic groups in the lack of depressions at the base of the hypopygidium and the pronotal posterior angles that project very far posteriorly.

\section{Melipriopsis rasnitsyni sp. $\mathbf{n}$.}

\section{Material examined}

(Figs 1-6)

Holotype, '28015 Nitidulidae', sex unknown; the well preserved and complete beetle is included in a clear amber parallelepiped $(5 \times 4 \times 2 \mathrm{~mm})$ with some pieces of dark organic matter and gas bubbles, which is additionally embedded in synthetic resin forming a larger parallelepiped $(9 \times 7 \times 5 \mathrm{~mm})$; the beetle integument is rather clear, although the head and some part of the lateral surface of the thorax are covered by a 'milky' layer.

\section{Etymology}

The epithet of this new species is devoted to Alexander P. Rasnitsyn, an outstanding palaeoentomologist, who has generously assisted the author in his studies over many years.

\section{Description (holotype)}

Length 3.0 , breadth 1.4 , height $0.7 \mathrm{~mm}$. Moderately convex dorsally and moderately convex ventrally; nearly light brownish; integument with a greasy shine; dorsum with comparatively stout, semi-erect, strongly conspicuous brownish hairs about as long as the distance between their insertions, although on head hairs somewhat shorter and denser, pronotal, elytral and hypopygidial sides, with moderately dense cilia; underside with less conspicuous and shorter hairs.

Head with distinct punctures, somewhat smaller than eye facets in diameter, interspaces between them markedly less than puncture diameter and apparently smoothly alutaceous. Pronotum, elytra and thoracic sclerites with slightly larger and sparser punctures, interspaces between them 1.5-2.0 times as great as puncture diameter, smoothly alutaceous. 
Pygidium with dense, small and shallow punctures intermixed by small and diffuse tubercles, interspaces between them smoothly alutaceous. Abdominal ventrites roughly as punctured and sculptured as most dorsal and thoracic sclerites, although puncturation becomes finer posteriorly.
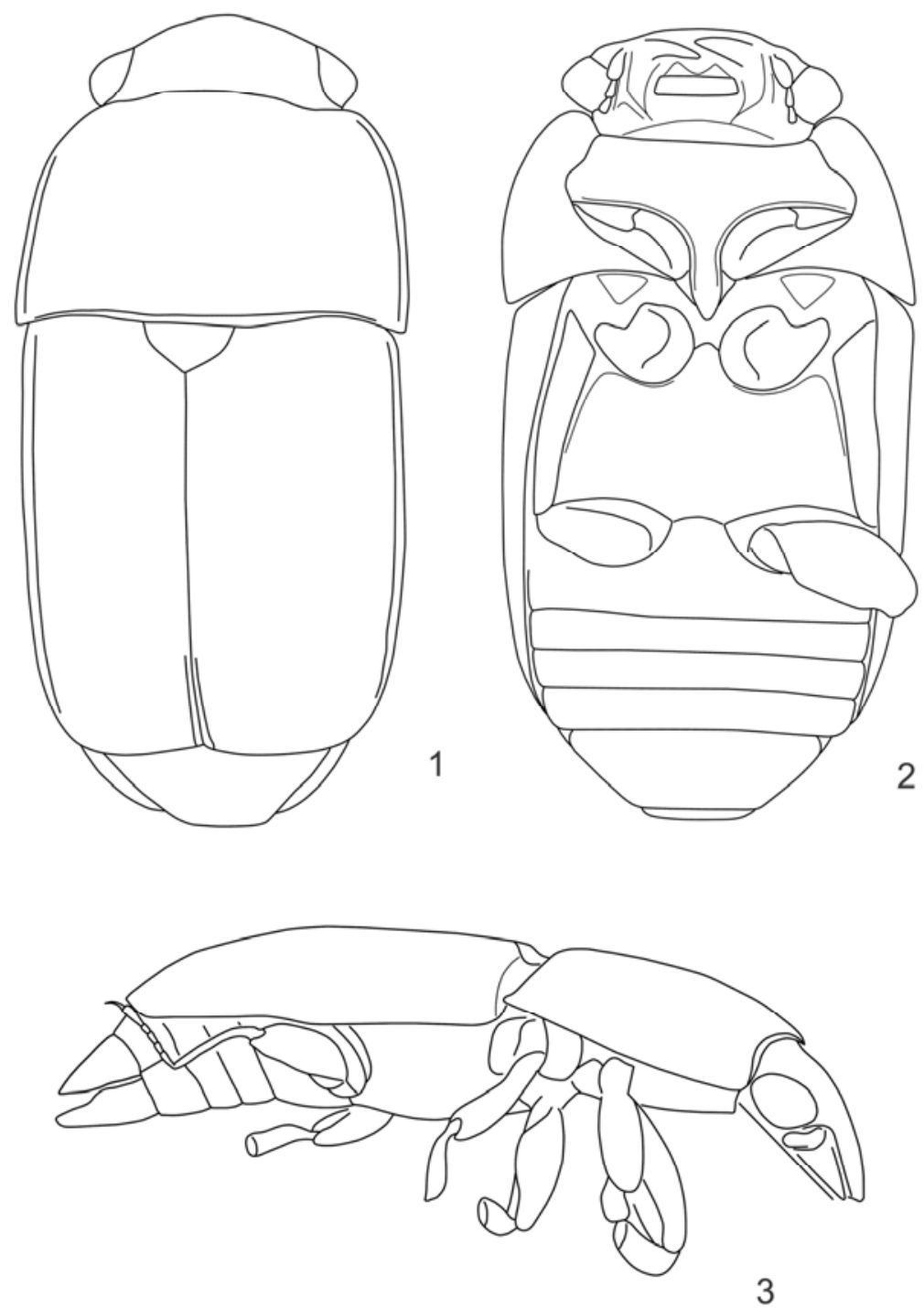

Figs 1-3. Melipriopsis rasnitsyni gen. et sp. n. (Nitidulidae): 1 - body, dorsal view, 2 - idem, ventral view, 3 - idem, lateral view. Length of body $3.0 \mathrm{~mm}$. 

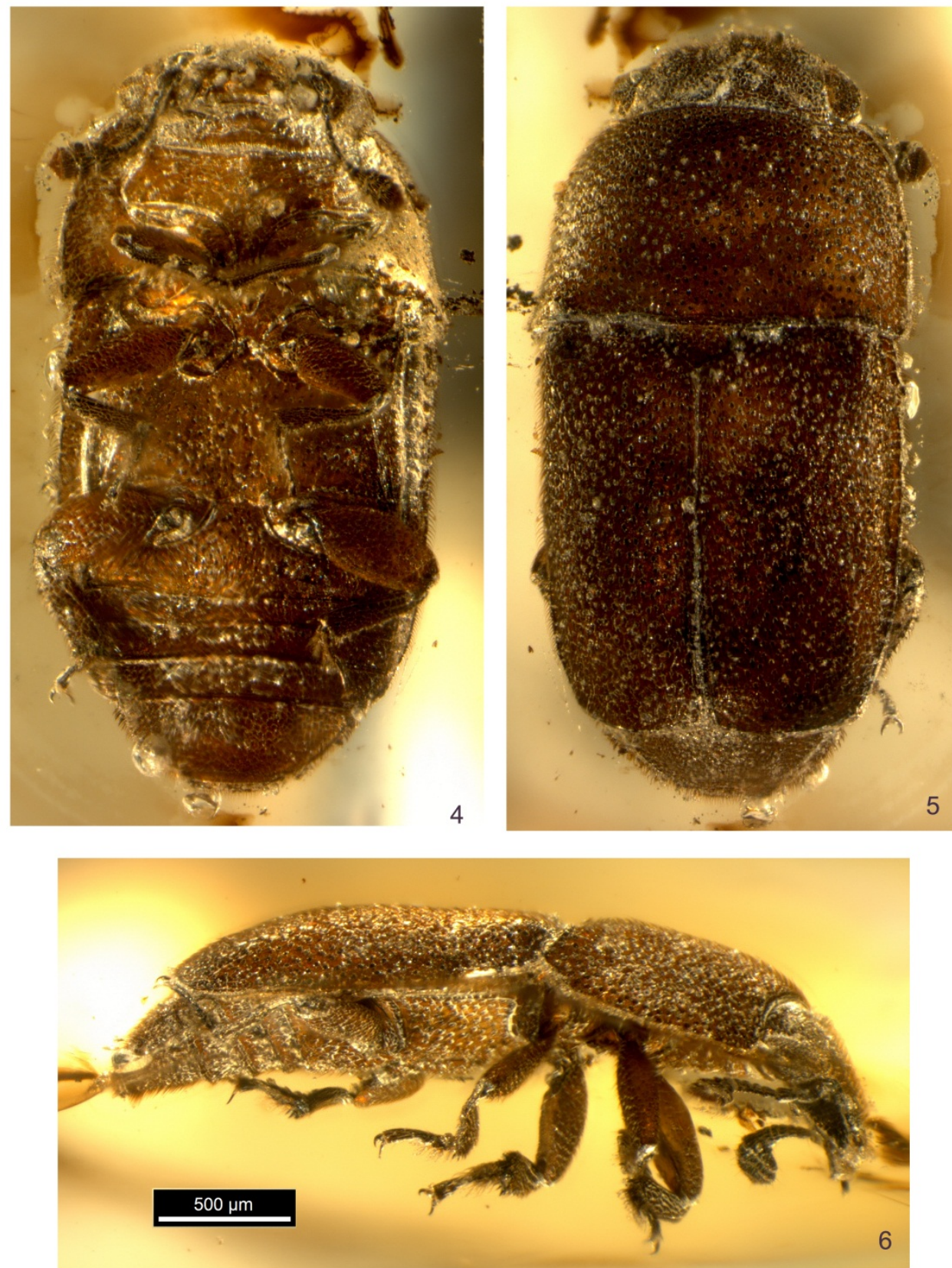

Figs 4-6. Melipriopsis rasnitsyni gen. et sp. n. (Nitidulidae): 4 - body, dorsal view, 5 - idem, ventral view, 6 - idem, lateral view. Length of body $3.0 \mathrm{~mm}$. 
Head subflattened and about as long as the distance between moderately large eyes (consisting of comparatively coarse facets), transverse diameter of the latter about a fourth of the distance between eyes, its anterior edge finely bordered, transverse and with rounded lateral angle. Lobes of labrum not visible. Antennae somewhat shorter than $3 / 4$ of head width; scape about 1.5 times as long as antennomere 2; antennomere 3 somewhat longer than antennomere 2 and about as long as the following antennomeres 4-8; 3-segmented antennal club makes up about $1 / 3$ of total antennal length, suboval, about 1.5 times as long as wide and with subacute ultimate antennomere. Pronotum widest at base and arcuately narrowing anteriorly, with evenly vaulted disk and gently sloping to narrowly subexplanate sides, anterior edge shallowly bi-emarginate, posterior edge bi-sinuate, posterior angles projecting posteriorly comparatively far, base distinctly bordered. Scutellum subpentagonal and with rounded apex, almost twice as wide as long. Elytra about 1 and 1/5 as long as wide combined, with maximum width in the middle and almost subparallel-sided, with truncate to very widely rounded apices, which form a very shallow sutural angle, steeply sloping to very narrowly subexplanate lateral edges, adsutural lines distinct at distal $1 / 4$. Pygidium slightly convex, widely rounded to subtruncate at apex.

Ultimate labial palpomere apparently slightly more than twice as long as thick. Mentum subtrapezoid, almost three times as wide as long. Antennal grooves distinct along inner edge, straight and comparatively short, postocular depression not expressed. Prosternum gently convex along the middle and with process slightly widened at subangular arrowliked apex, its maximum width about $2 / 3$ of width of antennal club. Distance between mesocoxae about as great as that between procoxae and that between metacoxae about twice as large. Metaventrite subflattened and with a weak and narrow median depression, with very distinct submesocoxal line following closely the posterior edge of cavity and arcuately deviating only at outer angle of metaventrite. Submetacoxal line following closely posterior edge of cavity. Abdominal ventrite 1 somewhat longer than ventrites 2-4 combined and slightly longer than hypopygidium, which is subtruncate. Epipleura gradually narrowing distally, slightly wider than antennal club and strongly sloping laterally.

Tibiae slightly narrower than antennal club and moderately long; protibia finely crenulate along outer edge, meso- and metatibiae with a row of small very short and dense setae along outer edge, spurs comparatively small and stout. Femora with usual outline and rather wide, 2.5-3.0 times as wide as prosternal process. Tarsi rather long (about 2/3 as long as tibiae), tarsomeres 1-3 moderately lobed, claw simple and narrow; protarsus about half as wide as protibia, meso- and metatarsi somewhat narrower. 
Family Silvanidae KIRBY, 1837

Subfamily Brontinae BLANCHARD, 1845

Tribe Brontini BLANCHARD, 1845

\section{Genus Dendrobrontes gen. $\mathbf{n}$.}

Type species: Dendrobrontes popovi sp. $\mathrm{n}$.

\section{Etymology}

The name of this new genus is formed from the roots of generic names used in Silvanidae: 'Dendrophagus' and 'Brontes'; gender masculine.

\section{Composition}

The new genus includes only the type species.

\section{Diagnosis}

Body medium-sized, elongate and subflattened; slightly and shortly pubescent. Integument with fine and sparse punctures, elytra with seriate puncturation on dorsal plane and dense and diffuse punctures on subvertical sides. Head subquadrate, with rather prominent parts of frons before antennal insertions. Labrum exposed, transverse. Antennae much longer than body and with annomeres 2 and 3 shortest with their combined length smaller than ultimate antennomere. Pronotum slightly longer than wide, with anterior edge as great as basal width of head and undulating sides. Scutellum subsemi-circular. Elytra complete, with completely flat dorsal plane separated from subvertical sides by a distinct carina, adsutural lines clear. Ultimate labial and maxillary palpomeres subconical and acuminate. Legs as in recent Dendrophagus species.

\section{Comparison}

The extant fauna of the tribe Brontini was recently revised by THOMAS $(2003,2011)$ and the new genus could be compared with the characteristics of the recent genera included in these publications. The new genus is very similar to Dendrophagus SCHÖNHERR, 1809 but differs from the latter in the very long antennae and elytra separated by a distinct carina into the flat dorsal plane with seriate puncturation and lateral vertical slope with diffuse puncturation, and also in the unicolorous body with dark appendages, acute apices of ultimate maxillary and labial palpomeres, somewhat shorter anterior part of frons, finer dorsal puncturation and very shallow punctures on elytra. Besides, in contrast to the recent species, Dendrobrontes popovi gen. et sp. n. has smaller temples, more prominent eyes, peculiar depressions on its head and somewhat longer frontal lobes before antennal insertions. The elytra of the new genus are similar to those in Uleiota LATREILLE, 1796 (Brontinae), although some species of the latter have the seriate puncturation on the elytral vertical sides. Nevertheless, all members of Uleiota can be easily separated from the new genus by the structure of their tarsi and prothoracic segment. Besides, the elytra of the new 
genus are also similar to those in Nausibius LENTZ, 1857 (Silvaninae); they differ, however, from the latter in the subparallel-sided and subflattened body, the long antennae without clubs and the peculiarly shaped prothoracic segment.

\section{Dendrobrontes popovi sp. $\mathbf{n}$.}

(Figs 7-13)

\section{Material examined}

Holotype, '1698-2', sex unknown; a well preserved and nearly complete beetle, with a partly exposed posterior wing but without the distal half of the right metatibia and tarsus, is included in a clear amber parallelepiped $(19.0 \times 10.0 \times 2.6 \mathrm{~mm})$ with some pieces of dark organic matter above the beetle and a piece of white inorganic matter at the knee of the right intermediate leg, one rounded and partly brownish crack along the knees of the anterior and intermedial legs, and also with a brownish crack at the posterior end of the beetle body; in addition, the beetle's integument is covered by a transparent layer which appears to be a bubble of gas apparently emitted by the beetle as it drowned in the fresh resin (although much of the elytra, pronotal disc, posterior part of metaventrite, and a considerable part of every abdominal ventrite remain uncovered). The amber piece is additionally embedded in synthetic resin forming a larger parallelepiped $(21.0 \times 13.0 \times 6.0 \mathrm{~mm})$.

\section{Etymology}

The epithet of this new species is devoted to Yury A. Popov, an outstanding palaeoentomologist, who has been in friendly contact with the author for many years.

\section{Description (holotype)}

Length 6.2 , breadth 1.2 , height $0.5 \mathrm{~mm}$. Subflattened dorsally and slightly convex ventrally; nearly subunicolorous dark brown with somewhat lighter palpomeres; integument with a well expressed shine; dorsum with rather short, recumbent, slightly conspicuous brownish hairs about as long as distance between their insertions or somewhat shorter; underside nearly glabrous or with scarcely conspicuous hairs along sides and on hypopygidium; elytral sides with a row of hairs becoming longer along apices.

Head and pronotum with distinct punctures, about as large as eye facets in diameter, interspaces between them on head as great as a puncture diameter or somewhat greater and apparently smooth, but puncturation on pronotum somewhat sparser. Elytra with 7 longitudinal rows of shallow, indistinct and rather coarse punctures intermixed by longitudinal rollers on each flattened disc, while their vertical sloping sides with irregular distinct punctures are coarser than those on other dorsal sclerites, interspaces between punctures smoothly alutaceous. Thoracic and abdominal sclerites with rather coarse and rather sparse punctures, disposed mostly at sides; interspaces between them rather smooth to alutaceous. Head underside and hypopygidium with rather fine and comparatively dense punctures. 


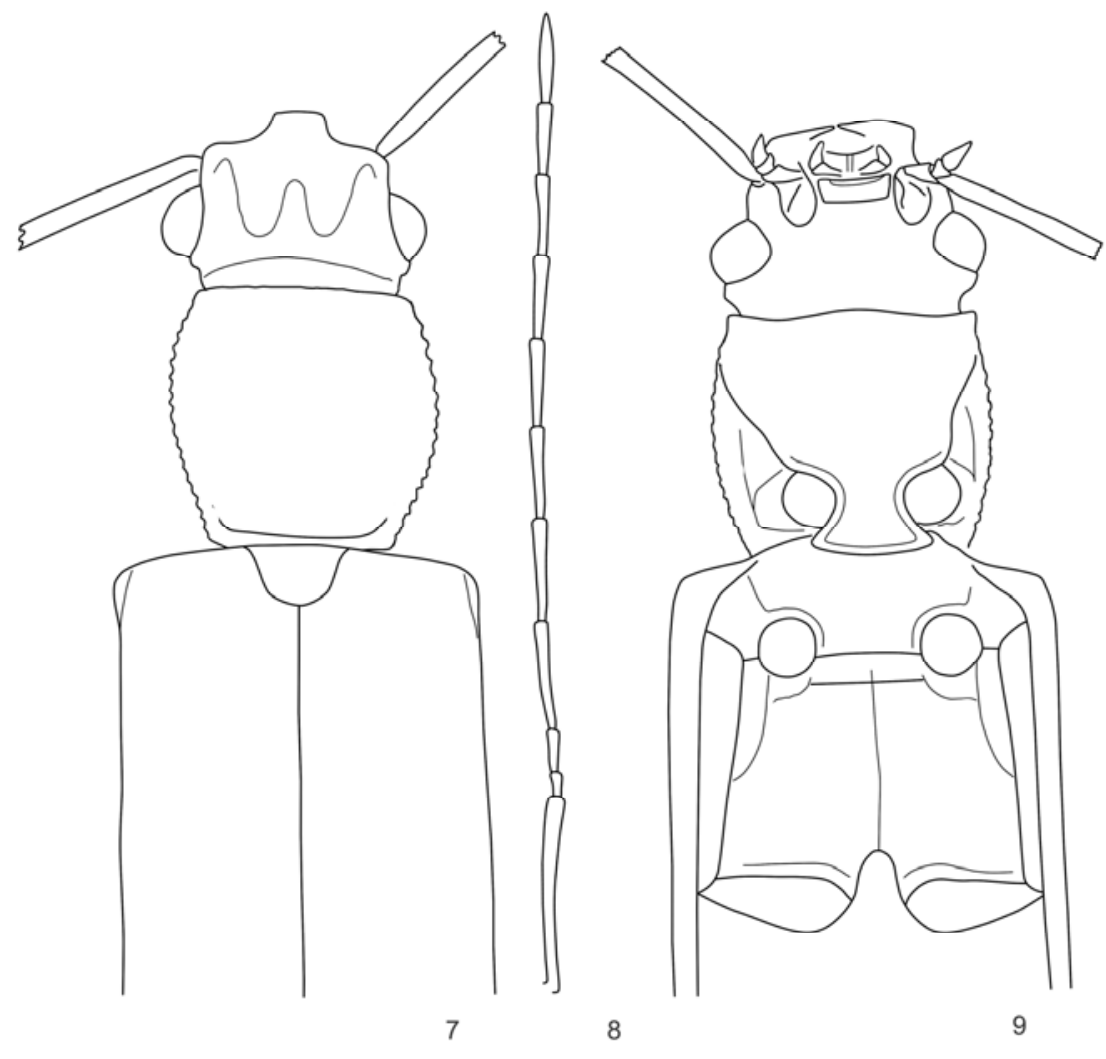

Figs 7-9. Dendrobrontes popovi gen. et sp. n. (Silvanidae): 7 - body without elytral apex, dorsal view, 8 - antenna, 9 - body without abdomen, ventral view. Scale bar for Figs $7 \& 91.3 \mathrm{~mm}$. Length of antenna $7.2 \mathrm{~mm}$.

Head subflattened and about as long as the distance between moderately large eyes (consisting of moderately coarse facets), its anterior edge transverse, temples very small; dorsal surface intersected by two longitudinal depressions starting before rather weak occipital ridge and joined with a transverse depression between antennal insertions. Labrum exposed, transverse, about 4 times as wide as long. Antennae about 1.4 times as long as body; scape about 1.5 times as long as pronotum or about as long as antennomeres 1-3 combined; antennomere 3 about twice as long as antennomere 2; antennomere 4 about 2.5 
times as long as antennomere 3; antennomeres 5-11 progressively shortening distally; ultimate antennomere acute at apex. Pronotum widest in the middle and gradually narrowing anteriorly and posteriorly, with subdepressed disk and line along base and posterior angles, sides somewhat undulate. Scutellum subsemi-circular, about 1 and 2/3 as wide as long. Elytra completely covering abdomen, about 1 and $2 / 5$ as long as wide combined, with maximum width in the middle and almost subparallel-sided, which are conjointly rounded, steeply sloping to very narrowly subexplanate lateral edges, adsutural lines distinct at distal $1 / 4$.

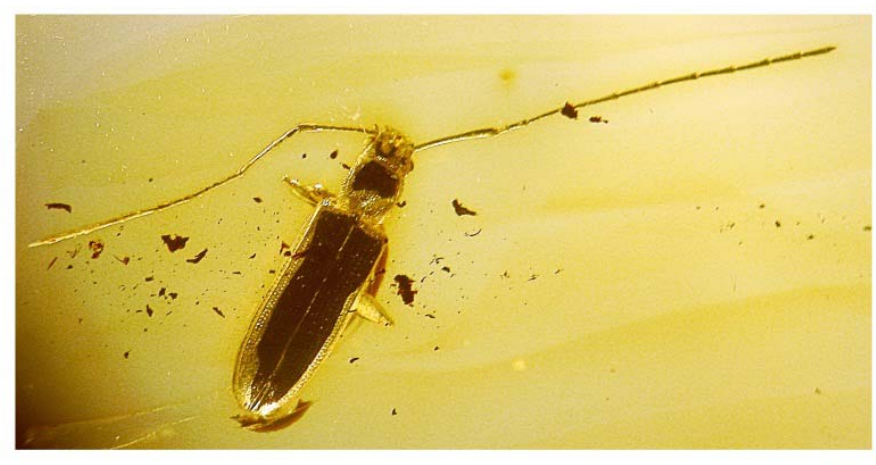

10

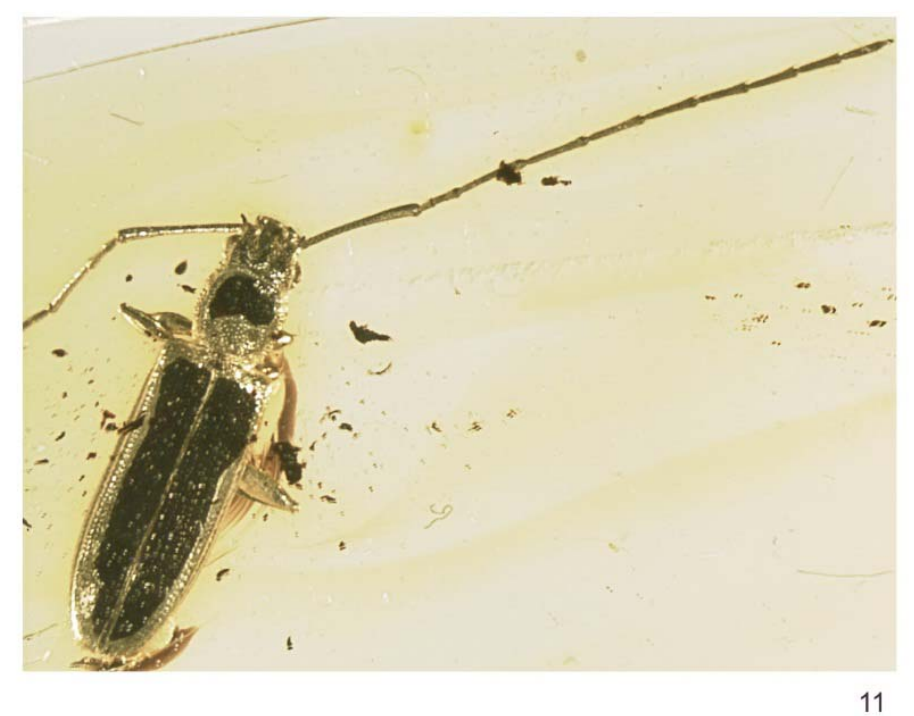

Figs 10, 11. Dendrobrontes popovi gen. et sp. n. (Silvanidae): body with appendages, dorsal view. Length of body $6.2 \mathrm{~mm}$. 

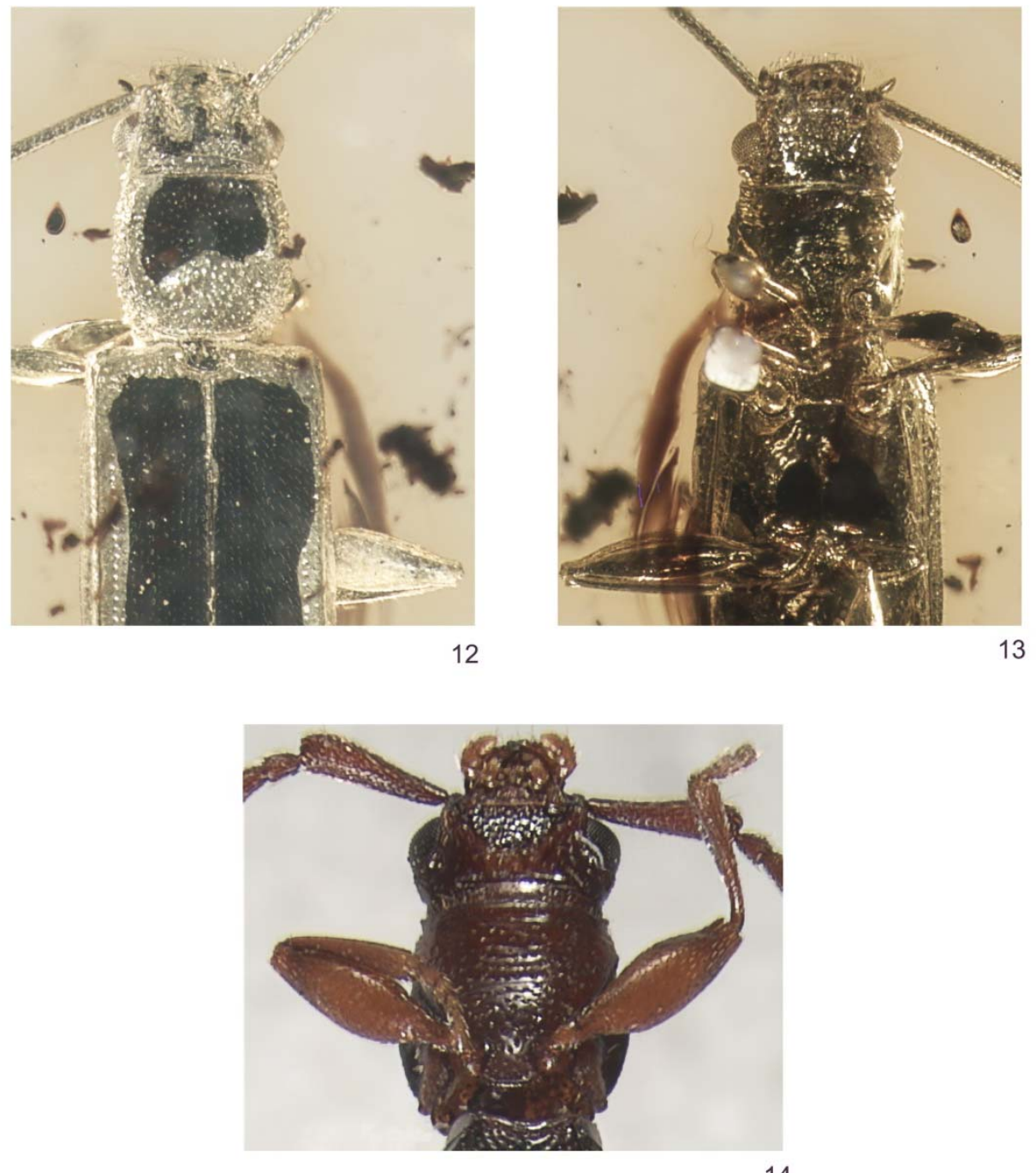

14

Figs 12-14. Dendrobrontes popovi gen. et sp. n. (12-13) and extant Dendrophagus crenatus (PAYKULl, 1799) (14) (Silvanidae): 12 - body without elytral apex, dorsal view, 13 - body without abdomen, ventral view (length $4.2 \mathrm{~mm}$ ), 14 - head and prothorax, ventral view (length $2.3 \mathrm{~mm}$ ).

Ultimate labial and maxillary palpomeres subconical, about twice as long as thick. Mentum subtrapezoid, almost four times as wide as long and narrowing anteriorly. Prosternum gently convex along the middle and with process widened at truncate apex, its 
maximum width about twice of width of each pro- or mesocoxae. Distance between mesocoxae about three times as great as that between metacoxae and that between procoxae about twice as great as that between metacoxae. Metaventrite subflattened and with a weak and narrow median depression, unified depression along anterior edge, mesocoxae and anterior halves of metepisterna; parametacoxal lines (metakatepisternal sutures) before metacoxae and median suture (discrimen) quite distinct. Abdominal ventrites 1-4 comparable in length and each slightly longer than hypopygidium, which is widely rounded at apex.

Legs as those in the recent congeners.

\section{DISCUSSION}

The genus Melipriopsis gen. $\mathrm{n}$. possesses a mixture of characters which demonstrates its archaic state in comparison with recent groups. The most expressive character is the bordered pronotal base, making it somewhat similar to some representatives of other subfamilies (Nitidulinae and Cryptarchinae) known from both recent and Cenozoic fossil faunas. Inclusions from Baltic amber have revealed some forms similar to recent species of Aethina ERICHSON, 1843 (Nitidulinae), Cryptarcha SHUCKARD, 1839 and Kaszabena KIREJTSHUK, 1987 (Cryptarchinae), which not only have the border along the pronotal base, but also the ellipsoid body shape, ciliate pronotal and elytral sides, and shortened elytra. However, the latter species are characterized by a prosternum with a wider prosternal process, thinner femora, not subflattened meso- and metatibiae with double rows of setae along their outer edge, and the members of the last two genera also have the labrum fused with the frons. The texture of all cranial structures, particularly the anterior part of the frons, palpi and antennal grooves, shape of scutellum of Melipriopsis rasnitsyni gen. et sp. $\mathrm{n}$. resemble those in the other members of Meligethinae rather than any other groups. Thus, it is thought reasonable to regard the characters distinguishing the new genus from the remainder of Meligethinae and partly similar to those in other subfamilies (distinct cilia along pronotal and elytral sides, border along pronotal base) as a consequence of the maintenance of archaic features.

The finding of Melipriopsis gen. $\mathrm{n}$. has brought new facts to light, on the basis of which previous hypotheses on the age of origin of the subfamily by KIREJTSHUK $(1992,1994)$ and the phylogenetic relationship inside the subfamily by AUDISIO et al. (2009) should be reconsidered. The subfamily may be not so old, because an archaic member of this lineage existed at the time of Baltic amber deposition. The new genus is certainly most similar to recent members of the nominotypic subgenus Meligethes in the body shape, character of puncturation and microsculpture, shape of antennal grooves, prosternal process, 
pterothoracic sclerites and so on. At the same time, in addition to the lack of hypopygidial depressions (as in Cryptarchopria, Cornutopria (including Microporodes and Palmopria) and Pria), the new genus has the pronotal posterior angles strongly projecting posteriorly (as in Cryptarchopria; Horakia JELÍNEK, 2000, Kabakovia KIREJTSHUK, 1979, Microporum WATERHOUSE, 1876 from another group of genera according to AUDISIO et al. 2009). Unfortunately, having proposed a new classification of the subfamily, the latter authors did not provide their construction with characters, which were used for creating the phylogenetic model published without any proper explanation. This circumstance makes it extremely difficult to understand and analyse this model. Admittedly, the similarity of the last abdominal segment in Melipriopsis gen. n. and Cryptarchopria is a symplesiomorphy (although not wholly evident), while the lack of depressions at the base of the hypopygidium in the rest of the above-mentioned genera seems to be a consequence of secondary reduction. These contradictions in the model by AUDISIO et al. (2009) force one to provide a more strongly grounded interpretation of the phylogeny of the subfamily.

The finding of Melipriopsis gen. $\mathrm{n}$. in Baltic amber as well as Meligethes in extratropical south-east Asia and Cryptarchopria in the recent Indo-Malayan Region illustrates the quite regular link between the biota of Baltic amber and that of modern southeast Asia ('Himalayan-Burman-Yunnanian block'), or even farther to the south-east, as mentioned in the publications of both zoologists and botanists (TAKHTAJAN 1970, FRAHM 1999, KIREJTSHUK \& KUROCHKIN 2010 etc.), although ZHERICHIN (1978) referred to other regularities in biotic links. This contradiction can be resolved by the ecological and bionomic peculiarities in different groups of organisms, as reflected in their history during the progressive climatic and biotic differentiations after the 'thermoera'. It should be noted that species of Cryptarchopria are now associated with palm inflorescences (Arenga pinnata (WURMB) MERRILL) in tropical and mountain forests (KIREJTSHUK \& KABAKOV 1997), while recent species of the subgenus Meligethes are known as inhabitants only of the flowers of arboreous and shrubby Rosaceae. The recent pan-Afro-Euro-Asian range of the genus Pria with some extension to the islands of the Indian and Pacific Oceans and to Australia (i.e. almost palaeotropical) could be regarded as a trace of the old range of the subfamily. The finding of Melipriopsis gen. n., combined with a preference for a dry subtropical climate by many recent archaic groups of the subfamily (Mediterranean, east and southern Africa), suggest a Thetian origin of the subfamily (KIREJTSHUK 1979).

Dendrobrontes gen. n. represents the first described fossil of the tribe Brontini. The recent fauna of this tribe is distributed mostly in the eastern Hemisphere, with some concentration of its diversity in the Holarctic, Indo-Malayan and Australian regions. The available data on its fossils are not sufficient for any meaningful discussion on the history of this tribe, although from the distribution of other silvanid groups in time, we can assume the Cretaceous origin of this tribe. 


\section{REFERENCES}

Audisio P., Cline A.R., De Biase A., Antonini G., Mancini E., Trizzino M., Costantini L., StRiKa S., LAmanna F., CERRETTI P. 2009. Preliminary re-examination of genus-level taxonomy of the pollen beetle subfamily Meligethinae (Coleoptera: Nitidulidae). Acta Entomologica Musei Nationalis Pragae 49: 341-504.

BACHOFEN-ECht A. 1949. Der Bernstein und seine Einschluesse. Springer Verlag, Wien, pp.: 1-204 + 1 pls. +188 figs.

DE JONG G. 1953. A “new” Nitidulid beetle from Sumatra. Zoologische Mededelingen 32(5): 43-47.

ERMisch K. 1942. Airaphilus n. sp. (Donacia spec. HeLM). Entomologische Blätter 38: 128-129.

FrAHM P. 1999. Die Laubmoosflora des Baltischen und Bitterfelder Bernstein. Mitteilungen des Geologisch-Paläontologischen Instituts der Universität Hamburg 83: 219-238.

HANDLIRSCH A. 1906-1908. Die fossilen Insekten und die Phylogenie der rezenten Formen: Ein Handbuch für Paläontologen und Zoologen. Leipzig: Wilhelm Engelmann, pp.: 1-1430.

Handlirsch A. 1925. Palaeontologie. [In:] SchröDER CH. (ed.). Handbuch der Entomologie, Jena Bd. 3: 1-1201.

Hieke F., PietrZeniuk E. 1984. Die Bernstein-Käfer des Museums für Naturkunde, Berlin (Insecta, Coleoptera). Mitteilungen aus dem Zoologischen Museum in Berlin 60(2): 297-326.

KIREJTSHUK A.G. 1979. Zhuki-blestyanki podsemeystva Meligethinae (Coleoptera, Nitidulidae) fauny SSSR [Sap beetles of the subfamily Meligethinae (Coleoptera, Nitidulidae) of the fauna of the USSR]. Authosynopsis of thesis for competition of scientific degree of candidate of biological sciences. Leningrad, Zoological Institute of USSR Academy of Sciences, pp.: 1-24.

KIREJTSHUK A.G. 1992. Znachenie antofagii $\mathrm{v}$ istoricheskom razvitii otryada zhestkokrykych (v osnovnom na primere semeystva zhukov-blestyanok [Significance of anthophagy in historical development of the order Coleoptera (mainly by the example of the family of sap-beetles)]. Authosynopsis of thesis for competition of scientific degree of doctor of biological sciences. St. Petersburg, Zoological Institute of Russian Academy of Sciences, pp.: 1-51.

KIREJTSHUK A.G. 1994. Sistema, evolyutzia obraza zhizni b filogeniya otryada zhukov (Coleoptera) [System, evolution of mode of life and phylogeny of the order Coleoptera]. I. Entomological review 73(2): 266-288.

KIREJTSHUK A.G., KABAKOV O.N. 1997. Notes on the sap-beetles (Coleoptera, Nitidulidae) collected by O.N. Kabakov in Vietnam and Laos [Zamechaniya o zhukakh-blestyankakh (Coleoptera, Nitidulidae), sobrannykh O.N. Kabakovym vo Vietname i Laose]. Kharkov Entomological Society Gazette 5(2): 13-23.

KirejtShUK A.G., KUROChKIN A.S. 2010. New species of sap beetles (Coleoptera: Nitidulidae: Nitidulini) from the Baltic and Bitterfeld ambers. Paleontological Journal 44(1): 53-67.

KirejtShuK A.G., Nel A. 2008. New beetles of the suborder Polyphaga from the Lowermost Eocene French amber (Insecta: Coleoptera). Annales de la Société entomologique de France (n.s.) 44(4): 419-442.

KIREJTSHUK A.G., PoINAR G. 2007. Species of paleoendemic sap beetle genera of the tribe Nitidulini (Nitidulidae: Coleoptera) from Baltic and Dominican amber. Paleontological Journal 41(6): 629-641.

Kirejtshuk A.G., Ponomarenko A.G. 1990. Fossil beetles of the families Peltidae and Nitidulidae (Coleoptera) [Iskopaemye zhuki semeystv Peltidae i Nitidulidae (Coleoptera)]. Paleontologichesky zhurnal № 2: 78-88.

KLEBS R. 1910. Über Bernsteineinschlusse im allgemeinen und die Coleopteren meiner Bernsteinsammlung. Schriften Phys.-okon. Gesellschaft. Konigsberg 51(3): 217-242.

KUROCHKIN A.S., KiREJTSHUK A.G. 2010. New species of sap beetles (Coleoptera: Nitidulidae: Epuraeinae, Cybocephalinae) from the Baltic amber. Paleontological Journal 44(5): 534-545. 
LARSSON S.G. 1978. Baltic Amber - a palaeobiological study. Entomonograph 1: 1-192.

Palmer A.R., Carvalho J.C.M., CoOK D.R., O'Neill K., Petrunkevitch A., Sailer R.I. 1957. Miocene arthropods from the Mojave Desert, California. United States Geological Survey, Professional Papers 294-G: 237-280.

PONOMARENKO \& KiREJTSHUK (2011 Catalogue of fossil Coleoptera. http://www.zin.ru/Animalia/Coleoptera/rus/paleosys.htm_ [accessed 1.09.2011], http://www.zin.ru/Animalia/Coleoptera/eng/paleosys.htm [accessed 1.09.2011]

RASNITSYN A.P., RosS A.J. 2000. A preliminary list of arthropod families present in the Burmese amber collection at the Natural History Museum, London. Bulletin of The Natural History Museum. Geology Series 56(1): 21-24.

RitZKOWSKI S. 1997. K-Ar-Altersbestimmungen der bernsteinführenden Sedimente des Samlandes (Paläogen, Bezirk Kaliningrad). Metalla, Bochum 66: 19-23.

SPAHR U. 1981. Systematischer Katalog der Bernstein- und Kopal-Käfer (Coleoptera). Stuttgarter Beiträge zur Naturkunde 80: 1-107.

TAKHTAJAN A.L.1970. Origins and dispersion of flowering plants [Proiskhozhdenie i rasprostranenie zvetkovykh rasteniy]. Nauka, Leningrad, pp.: 1-146.

THOMAS M.C. 2004. The Brontini of the world: a generic review of the tribe (Coleoptera: Silvanidae: Brontinae). Insecta_Mundi 17(1-2): 1-31.

Thomas M.C. 2011. A new genus and species of brontine Silvanidae from Australia (Coleoptera: Cucujoidea). Insecta Mundi 0154: 1-8.

Weitschat W., Wichard W. 2010. Baltic amber. [In:] Penney D. (ed.) Biodiversity of fossils in amber from the major World deposits. Siri Scientific Press, Manchester, pp.: 80-115.

Wickнам H.F. 1920. Catalogue of the North American Coleoptera described as fossils. 347-365. [In:] LENG C.W. (eds). Catalogue of the Coleoptera of America North of Mexico. Mt. Vernon, New York, pp.: 1-470.

WiCKHAM H.F. 1933. Second supplement to catalogue of the North American Coleoptera described as fossils. Supplement 1925 to 1932 to Leng's. Catalogue of the Coleoptera of America north of Mexico. J.D. Sherman, Mount Vernon, N.Y., pp.: 103-105.

ZHERICHIN V.V. 1978. Razvitie i smena melovykh i kaynozoyskikh faunisticheskikh komplexov (trakheynye I khelitzerovye) [Development and change of the Cretaceous and Cainozoic faunal complexes (Tracheata and Chelicerata)]. Trudy Paleontologicheskogo institut AN SSSR [Proceedings of Paleontological Institute of the USSR Academy of Sciences] 165: 1-198.

Received: September 7, 2011

Accepted: December 7, 2011 